\title{
A MOTHER AND SON'S FIRST NATURE TRAIL EXPERIENCE
}

\section{CAROL MERASTY, Box 191, Loon Lake, Saskatchewan. SOM 1 Lo}

It was the third week of January 1992 and another cold spell had just ended for the residents of Loon Lake, Saskatchewan. This was followed by a warm spell, with the temperature hovering between $0^{\circ} \mathrm{C}$ and $-3^{\circ} \mathrm{C}$. It was the perfect opportunity to take my four year old son for a refreshing nature walk after being cooped up indoors for days. The sun was shining brightly in this mid-afternoon and a light breeze was blowing through the trees.

The trail we followed was the Loon Lake Winter Nature Trail which is also used as a cross-country ski trail. I did not expect to get very far along the $2.4 \mathrm{~km}$ trail, but that was not the purpose of the outing.

The trail was packed down but the snow was soft and deep alongside it. The first thing my son, Tim, did was to step off the trail and sink into the snow. I brought my binoculars and a bird field guide which my son wanted to hold. He knew we were looking for "birdies" and he tried to hold the binoculars for a while but they were too heavy for him.

I had heard some birds calling when we first arrived but all was quiet now. We spent some time looking at the different shapes the tree shadows made on the snow. My son spotted the first bird, which might have been a Pine Grosbeak, followed by some species of chickadee (Boreal or Black-capped). His eyes were soon eagerly scanning the treetops for more birds. A Red Squirrel chattering away at us from a Jack Pine caught our attention. We went to the tree and I showed Tim the feeding site where the remains of cones were scattered around. He soon spotted other piles around the tree. An old bird's nest was right above our heads and again Tim's eyes caught another nest further up the tree which I had missed.

We explored along the trail, passing through stands of tamarack, paper birch, spruce and Jack Pine. A beer bottle was sticking out of a branch along the trail and Tim said, "That's not nice, right Mom?" I told him he was right. We explored the trail and looked at conks, woodpecker holes in an aspen and last year's sap on the trees by the trail. We soon made a game out of who noticed a hole or conk first.

It was getting late and Tim was also tiring so I made a beeline for the road through the deep snow. It was $30 \mathrm{~m}$ away and by the time we reached the road all my son had to say was, "Oh, my legs." As I laughed my way down the road, I thought it was just the right note on which to end a wonderful outing. The experience proved to be very valuable in exposing a young child to the enjoyment that could be derived from nature and the outdoors. 